Article

\title{
Manganese Catalysts with Tetradentate N-donor Pyridine-Appended Bipiperidine Ligands for Olefin Epoxidation Reactions: Ligand Electronic Effect and Mechanism
}

\author{
Fengfan Zhu ${ }^{1, *}$, Guang Yang ${ }^{1}$, Adam J. Zoll ${ }^{1}$, Elena V. Rybak-Akimova ${ }^{1}$ and Xinbao Zhu ${ }^{2, *}$ \\ 1 Department of Chemistry, Tufts University, Medford, OR 02148, USA; guangyang11231987@gmail.com (G.Y.); \\ adam.zoll@tufts.edu (A.J.Z.); elena.rybak-akimova@tufts.edu (E.V.R.-A.) \\ 2 College of Chemical Engineering, Nanjing Forestry University, Nanjing 210037, China \\ * Correspondence: fengfan.zhu@tufts.edu (F.Z.); zhuxinbao@njfu.com.cn (X.Z.); Tel.: +86-139-5177-3063 (X.Z.)
}

Received: 31 January 2020; Accepted: 18 February 2020; Published: 2 March 2020

\begin{abstract}
In this work, we described an electron-rich manganese mesoPYBP catalyst, Mn-SR-meso PYBP $\left(\mathrm{ClO}_{4}\right)_{2}$, by introducing electron-donating substituents on the mesoPYBP ligand. We optimized the catalytic performance in olefin epoxidation with $\mathrm{H}_{2} \mathrm{O}_{2}$ in the presence of acetic acid. The electron paramagnetic resonance (EPR) and cyclic voltammetry (CV) studies supported that an electronic effect could stabilize the high-valent intermediates in the catalytic cycles of the catalyst, which largely improved the catalytic performance and the reactivity of olefin epoxidation.
\end{abstract}

Keywords: manganese catalyst; PYBP ligand; epoxidation

\section{Introduction}

Epoxides are important building blocks in various chemical reactions for pharmaceuticals and fine chemicals. They transform readily to a wide variety of functional groups including ketones, ethers and alcohols by reduction, rearrangement or ring-opening reactions [1-5]. The increasing demand for epoxides has raised research interest in developing efficient, low-cost and environmentally-benign synthetic methods [6-8]. Transition metals coordinated to tetradentate $\mathrm{N}$-donor (4N) aminopyridine ligands, such as BPMEN ( $N, N^{\prime}$-dimethyl- $N, N^{\prime}$-bis(2-pyridylmethyl)-1,2-diaminoethane) [9,10], BPMCN ( $N, N^{\prime}$-bis(2-pyridylmethyl)- $N, N^{\prime}$-dimethyl-trans-1,2-diaminocyclohexane) [11-14] and BPBP ( $N, N^{\prime}$-bis(2-picolyl)-2,2'-bipyrrolidine) [14-19], are now proven, efficient catalytic systems for the epoxidation of unfunctionalized olefins by using $\mathrm{H}_{2} \mathrm{O}_{2}$ as a green and atom-economical oxygen source. Carboxylic acid additives, such as acetic acid, promote the efficiencies of these epoxidations $[4,15,18]$. The first-row transition metals that complex with these ligands are abundant, cheap and environmentally friendly $[17,20]$. In a recent study, these metal complexes, however, were found to suffer from suboptimal selectivity, as the mixtures of cis-diols and epoxide products that result from these reactions are not easy to separate $[1,21]$. Addressing this challenge requires new olefin epoxidation catalysts.

In response to this challenge, our research group recently designed a family of bioinspired tetradentate $\mathrm{N}$-donor pyridine-appended bipiperidine ligands (PYBP-1,1'-bis[(pyridin-2-yl)methyl]$2,2^{\prime}$-bipiperidine) $[1,22,23]$. Those newly developed PYBP ligands were derived from bipiperidine, a six-member-ring platform, separated into racemic and mesomeric diastereomers, and then complexed with manganese $(\mathrm{Mn})$ or iron $(\mathrm{Fe})$ to catalyze olefin epoxidation (Scheme 1). We have previously reported that iron racPYBP catalyzed olefin epoxidation with faster rates and a higher regioselectivity than the catalysts prepared from the aforementioned ligands [23]. We attribute this improved performance to the rigidity in the ligand backbone frameworks, preventing metal decomplexation 
and the decomposition of the catalysts [24-26]. We have also investigated the impact of the isomer $\mathrm{M}^{\mathrm{II}}$-racPYBP and $\mathrm{M}^{\mathrm{II}}$-mesoPYBP complexes $\left(\mathrm{M}^{\mathrm{II}}=\mathrm{Mn}\right.$ and $\left.\mathrm{Fe}\right)$ on catalysis $[1,12,23]$. Catalysts based on the racPYBP ligand showed an excellent epoxidation reactivity at low loadings $(0.5 \mathrm{~mol} \%)$, while metal complexes based on the mesoPYBP ligand had either a slower reactivity (with $\mathrm{Fe}$ ), or were inactive (with $\mathrm{Mn}$ ). In this case, improving the reactivity of the mesomeric diastereomer complexes makes the PYBP catalytic system a more efficient and cheaper candidate for olefin epoxidation.

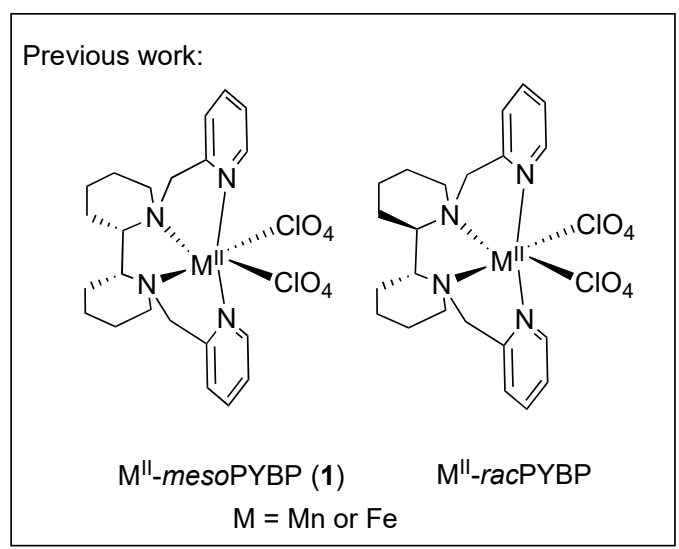<smiles>[R]C([R])=C([R])[R]</smiles>

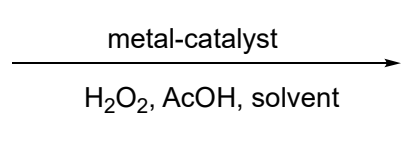

Current work:

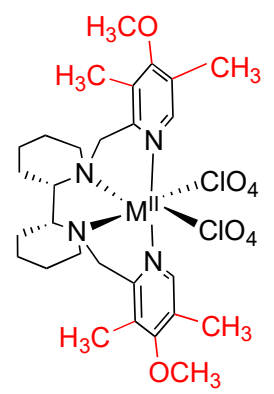

M"I-SR-mesoPYBP (2) $\mathrm{M}=\mathrm{Mn}$<smiles>[R]C1([R])OC1([R])[R]</smiles>

Scheme 1. PYBP (1,1'-bis[(pyridin-2-yl)methyl]-2,2'-bipiperidine)-catalyzed olefin epoxidation reaction.

Herein, we describe a new complex, Mn-SR-mesoPYBP $\left(\mathrm{ClO}_{4}\right)_{2}$ (Complex 2), which introduces electron-donating substituents on the pyridine rings of the PYBP ligand and complexes with manganese (Scheme 1). Several investigations in the field have discussed the ligand electronic effects on manganesecatalyzed alkene epoxidation, and we chose methoxy substituents on the PYBP ligands, because they are known to stabilize high oxidation state metallic intermediates in the catalytic cycle of BPBP catalysts $[16,17,21,27,28]$. Compared with the inactive Mn-mesoPYBP $\left(\mathrm{ClO}_{4}\right)_{2}(\mathrm{Complex} 1)$, Complex 2 yields faster olefin epoxidations, and exhibits a general relationship between the electronics of the ligands and the catalytic activity. The electron paramagnetic resonance (EPR) and cyclic voltammetry (CV) studies support our conclusion that the electronic effects can stabilize the high-valent intermediates in these catalytic cycles.

\section{Results and Discussion}

Scheme 2 shows our approach for preparing manganese Complex 2 from meso-bipiperidine, which incorporates electron donating methyl and methoxy groups into the axial pyridine ligands. We prepared fully reduced bipiperidines (BP), as reported in the literature $[1,6,23]$. The GC-MS (Gas Chromatography-Mass Spectroscopy) analysis of the mixture resulting from the reduction of $2,2^{\prime}$-bipyridine revealed that $70 \%$ of the mixture was mesomeric stereoisomers. The addition of $\mathrm{HBr}$ and heating to $40{ }^{\circ} \mathrm{C}$ produced the mesoBP ammonium salt, as a white precipitate. The alkylation of bipyridine with commercially available 4-methoxy-3,5-dimethylpicolyl chloride yielded the SR-mesoPYBP ligand. Complexation with manganese salt under argon protection and isolation by filtration gave the target Complex 2. ESI-MS (Electrospray Ionization-Mass Spectroscopy), NMR, elemental analysis and single crystal X-ray crystallography (see in Supplementary Information) were used to characterize the identity and purity of the SR-mesoPYBP ligand and its manganese complex. 


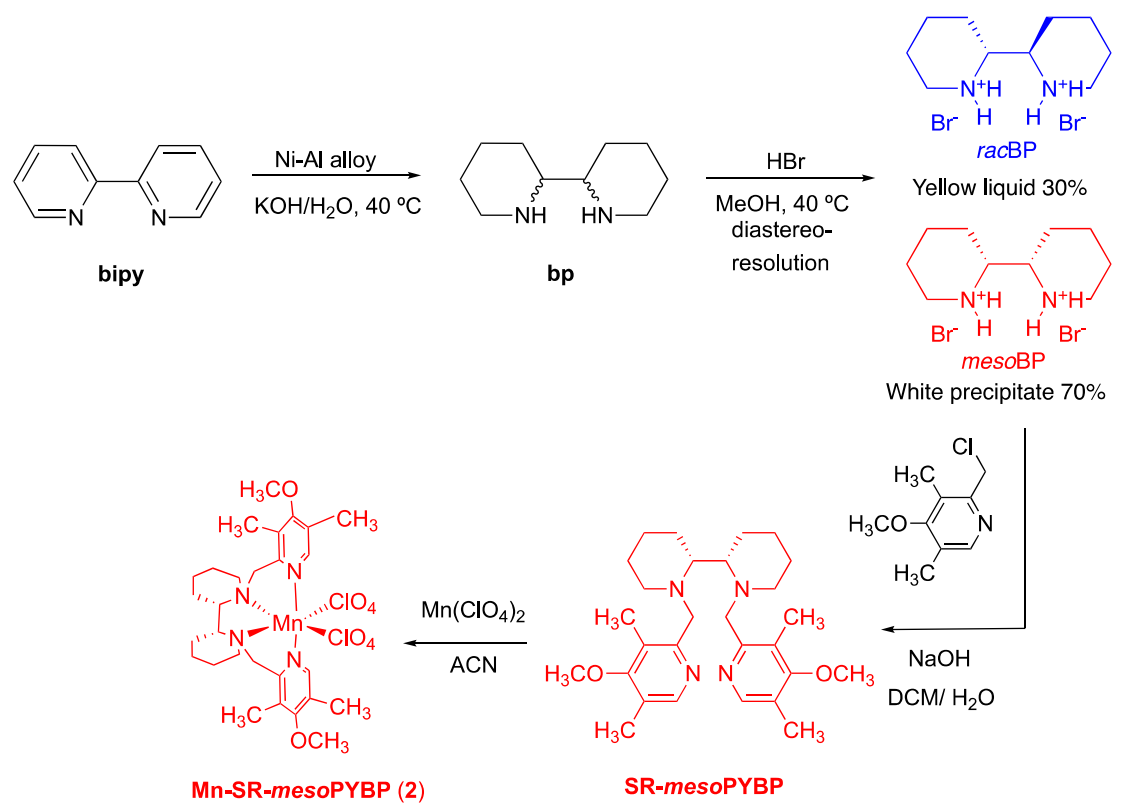

Scheme 2. Synthesis of Complex 2.

The catalytic performance of Complex 1 and 2 with cyclooctene in $\mathrm{H}_{2} \mathrm{O}_{2}$ and acetic acid was investigated and optimized. The epoxidation yields were quantified by GC-MS, with chlorobenzene as an internal standard. As shown in Figure 1, Complex 2 exhibited some catalytic activity-up to a 100\% conversion and $76 \%$ yield within 30 min-while Complex 1 was catalytically inactive.
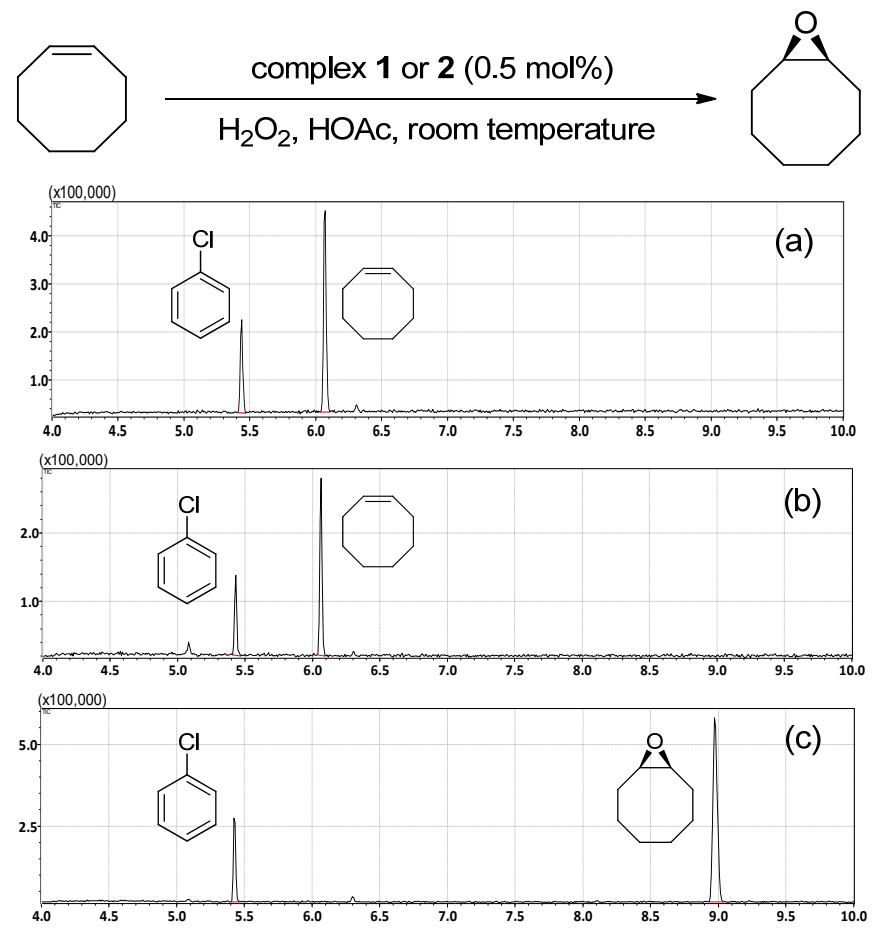

Figure 1. Catalytic performance of olefin epoxidation: (a) no catalyst, (b) manganese mesoPYBP and (c) SR-mesoPYBP in GC-MS. Reaction conditions: catalyst $(0.5 \mu \mathrm{mol})$, cyclooctene $(100 \mu \mathrm{mol})$, chlorobenzene internal standard $(40 \mu \mathrm{mol}), \mathrm{H}_{2} \mathrm{O}_{2}$ ( $30 \%$ aqueous solution), HOAc (glacial) in $0.5 \mathrm{~mL}$ of acetonitrile, at room temperature. $\mathrm{H}_{2} \mathrm{O}_{2}$ was added in five equal portions in the first $4 \mathrm{~min}$. Standard: $5.5 \mathrm{~min}$, cyclooctene: $6 \mathrm{~min}$, cyclooctene oxide: $9 \mathrm{~min}$. 
The investigation of the acid loading revealed that the addition of a large excess of acid improved the olefin epoxidation yield with Complex 2 up to a point. As shown in Figure 2, the epoxidation yield increased dramatically from $15 \%$ to $70 \%$ by adding 2000 equiv. acetic acid. However, a high acid loading may also challenge the stability of Complex 2 , and too much acid may lead to a complex decomposition and reduced catalytic activity. It is also worth noting that unlike Complex 1, Complex 2 is catalytically active in olefin epoxidation, even in the absence of acetic acid.

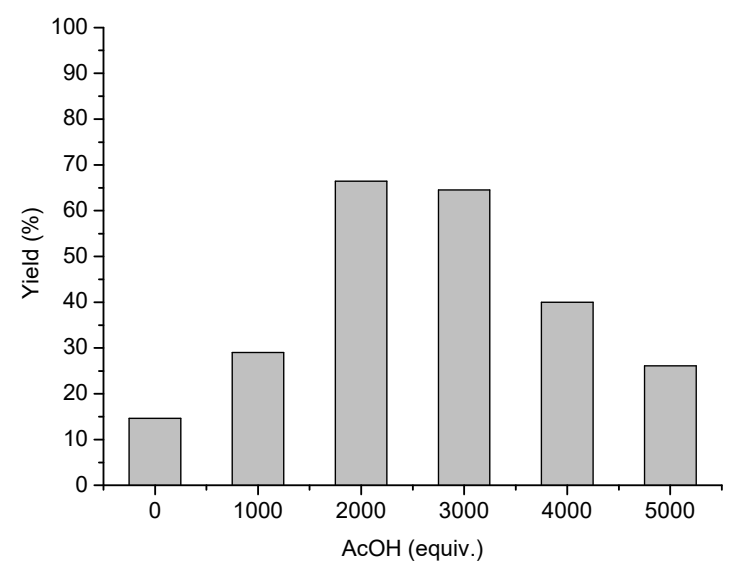

Figure 2. Investigation on acid loading for Mn-SR-mesoPYBP $\left(\mathrm{ClO}_{4}\right)_{2}$-catalyzed epoxidation.

The limiting reagent test was designed to find the limiting reagent in this epoxidation reaction. The results supported that the consumption of the active Complex 2 limited the catalytic yield of olefin epoxidation. This is mainly caused by the leakage of manganese ions from the complexes during the reaction, for which ESI-MS confirmed the demetallation and the formation of free ligands (see Figure S5). As shown in Figure 3, the epoxidation reactions were initially performed for 30 min under a standard condition, and adding a fresh catalyst (with oxidant) could resume the catalytic activity of Complex 2. However, adding substrates, oxidants or substrates and oxidants cannot restore the catalytic activity. Moreover, adding fresh manganese salt to the reaction after $30 \mathrm{~min}$ did not assist the catalysis. Similar experiments have been conducted with $\mathrm{Mn}-m e s o \mathrm{PYBP}\left(\mathrm{ClO}_{4}\right)_{2}$ and $\mathrm{Mn}\left(\mathrm{ClO}_{4}\right)_{2}$, but both showed no catalytic reactivity.

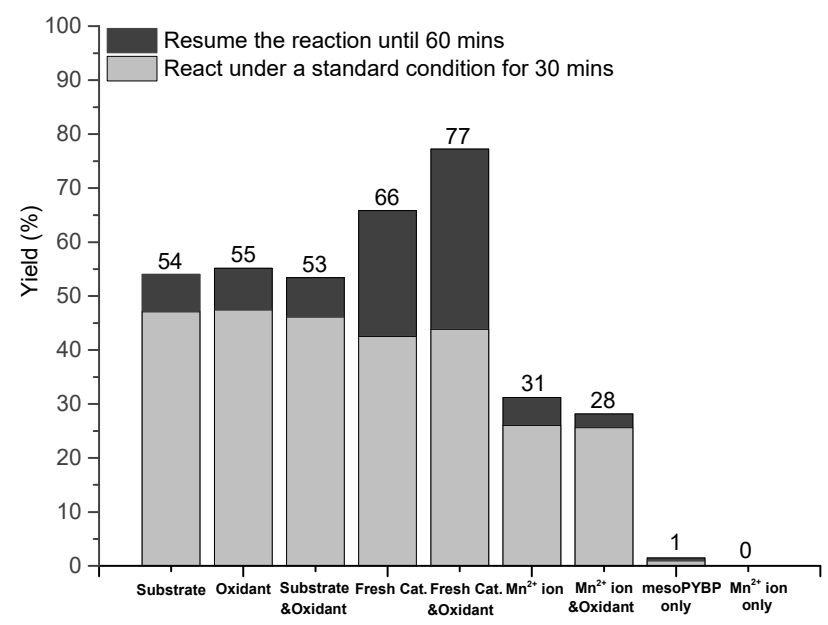

Figure 3. Limiting reagent test by GC for Complex 2 catalyzed epoxidation.

The cyclic voltammetry test demonstrated that Complex 2 is more stable than Complex 1 at higher oxidation states. Complexes 1 or $2(1 \mathrm{mM})$ with $0.1 \mathrm{M}$ electrolytes (tetra-n-butyl ammonium hexafluorophosphate) were prepared in $5 \mathrm{~mL}$ of acetonitrile. Two drops of $0.1 \mathrm{mM}$ Ferrocene were then added as a reference (red stars in Figure 4.). Complex 1 showed one reversible process $\left(E_{1 / 2}\right)$ 
at $0.56 \mathrm{~V}$ and Complex 2 showed a similar reversible process at $0.44 \mathrm{~V}$. These two redox potentials indicate the redox couples of $\mathrm{Mn}^{\mathrm{III} / \mathrm{II}}$ [20,29]. Earlier studies have suggested that the high electron density (basicity) and better steric accessibility of the donor atoms to the metal can lower the redox potentials and stabilize the higher oxidation states $[1,20]$. The lower redox potential of Complex 2 indicates that the higher electron density of the ligands (electron-rich PYBP ligands) contributes to the stability of the high oxidation states in the catalytic cycle

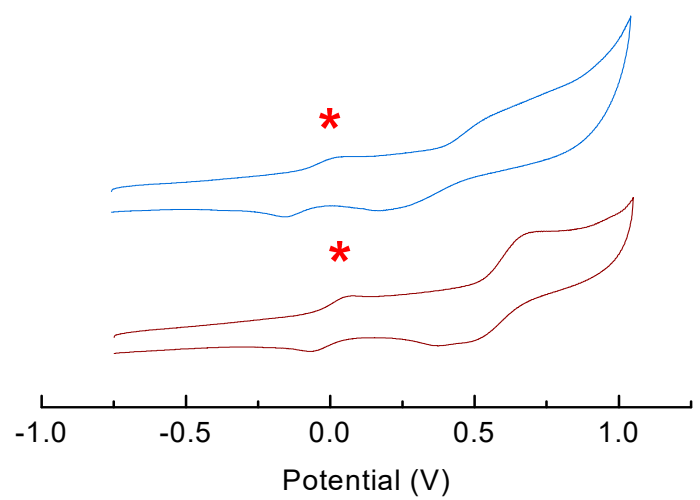

Figure 4. Cyclic voltammetry of Complexes 1 (red line) and 2 (blue line; Ferrocene was referenced by the star).

The EPR study was performed with $1 \mathrm{mM}$ of Complexes 1 or 2, with $20 \mathrm{mM} \mathrm{H}_{2} \mathrm{O}_{2}$ and $20 \mathrm{mM}$ acetic acid after 30 mins. All of the samples were prepared in acetonitrile, and then frozen in liquid nitrogen at $120 \mathrm{~K}$. As seen in Figure 5, Complex 2 showed a six-line spectrum of $\mathrm{Mn}^{\mathrm{II}}$ free ions superimposed over a 16-line spectrum of the mixed-valence binuclear $\mathrm{Mn}{ }^{\mathrm{III}} / \mathrm{Mn}^{\mathrm{IV}}$ intermediates [26,30]. However, Complex 1 only showed the $\mathrm{Mn}^{\mathrm{II}}$ ion spectrum, and could not be oxidized to a higher oxidation state, which indicates the catalytic inactivity of Complex 1. It is also worth noting that the EPR data of Complex 2 started to form a broad peak at $\mathrm{g}=4.54$, which represents an $\mathrm{Mn}^{\mathrm{IV}}$ intermediate [31]. This evidence indirectly supported that the electronic effect assisted in maintaining the manganese in the center of Complex 2 and successfully stabilizing the high-valent intermediates. Therefore, Complex 2 was catalytically active, while Complex 1 decomposed.

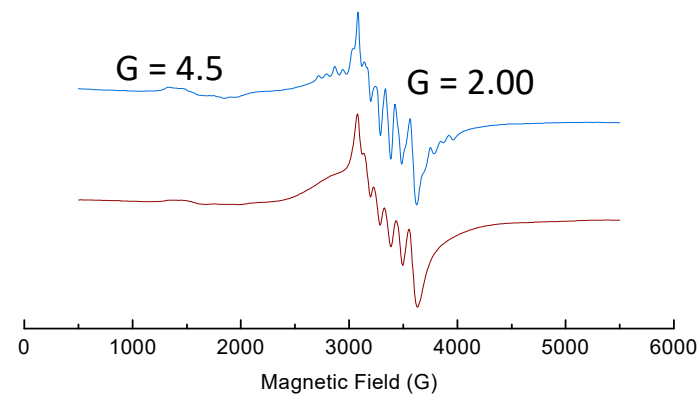

Figure 5. Electron paramagnetic resonance (EPR) study of manganese Complexes 1 (red line) and 2 (blue line) with $20 \mathrm{mM}$ of $\mathrm{H}_{2} \mathrm{O}_{2}$ in the presence of $20 \mathrm{mM}$ of $\mathrm{AcOH}$ after $30 \mathrm{~min}$.

An acid-assisted mechanism is proposed in Scheme 3, similar to the related work with BPBP and other ligand systems $[4,15,18,19,32,33]$. The active $\mathrm{Mn}^{\mathrm{II}}$ catalysts can react with $\mathrm{H}_{2} \mathrm{O}_{2}$ in the presence of acetic acid, and form $\mathrm{M}^{\mathrm{III}} \mathrm{OOH}(\mathrm{HCOOR})$ intermediates through an acid-assisted pathway. Talsi and co-workers speculated that high-valent $\mathrm{M}^{\mathrm{V}}=\mathrm{O}$ was the key intermediate, which allowed oxygen transformation to happen in analogous metal catalyst systems [34]. However, there was no direct evidence to prove the existence of an $\mathrm{M}^{\mathrm{V}}=\mathrm{O}$ intermediate in the PYBP catalytic cycle. Instead, mixed-valence binuclear $\mathrm{Mn}^{\mathrm{III}} / \mathrm{Mn}^{\mathrm{IV}}$ intermediates were present after the heterolytic $\mathrm{O}-\mathrm{O}$ 
bond cleavage based on the EPR data. Therefore, further mechanistic studies are needed to confirm the existence of $\mathrm{Mn}^{\mathrm{V}}=\mathrm{O}$ in the PYBP system.

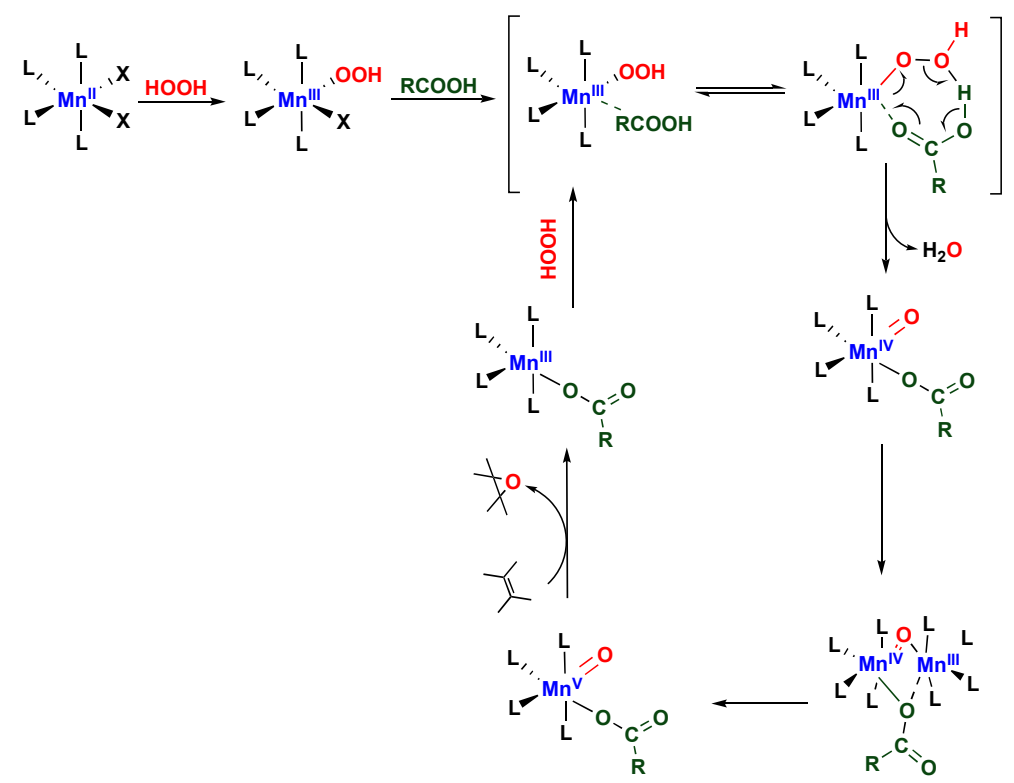

Scheme 3. Proposed mechanisms for the PYBP catalytic system.

\section{Materials and Methods}

\subsection{General}

All of the chemicals and solvents were purchased from Sigma Aldrich (St. Louis, MO, USA ) or Fisher Scientific (Waltham, MA, USA) and were used without additional purification, unless otherwise noted. The ESI-MS data were monitored using ThermoFinnigan Electrospray Mass Spectrometry (ESI-MS) and a LTQ-LCQ ion trap mass spectrometer in the positive ion detection mode before and after the workup (ThermoFinnigan, San Jose, CA, USA). Pure acetonitrile was used as the solvent. ${ }^{1} \mathrm{H}$ NMR and ${ }^{13} \mathrm{C}$ NMR were performed on a Bruker Avance III NMR spectrometer at $500 \mathrm{MHz}$ (Bruker, Billerica, MA, USA). $\mathrm{CD}_{3} \mathrm{Cl}$ was used as the solvent. The elemental analysis was conducted at the Microanalysis Laboratory School of Chemical Sciences, University of Illinois, Urbana-Champaign. The GC-MS experiments were carried out using a Shimadzu GC-17A gas chromatograph (Rtx-xLB column) with a GC-MS-QP 5050A mass detector (Shimadzu, Japan). The cyclic voltammetry experiments were performed on an EG\&G PAR 273 potentiostat using a three-electrode cell with a glassy carbon working electrode and platinum wire counter- and reference-electrodes. The EPR spectra were acquired on a Bruker EMX EPR spectrometer at $120 \mathrm{~K}$ (Bruker, Billerica, MA, USA).

\subsection{Synthesis of SR-MesoPYBP Ligand}

Meso BP·2HBr (3.19 g, $9.66 \mathrm{mmol})$ and SR-picolyl chloride hydrochloride (4.29 g, $19.32 \mathrm{mmol}, 2$ equiv) were separately dissolved in deionized water. $\mathrm{An} \mathrm{NaOH}$ solution (12 mL, $77.28 \mathrm{mmol}, 8$ equiv) was prepared by mixing a concentrated $\mathrm{NaOH}$ aqueous solution $(4.1 \mathrm{~mL}, 17 \mathrm{M})$ and deionized water $(7.9 \mathrm{~mL})$. A diluted $\mathrm{NaOH}$ solution $(6 \mathrm{~mL}, 4$ equiv) was added into the meso $\mathrm{BP} \cdot 2 \mathrm{HBr}$ solution and stirred for $1 \mathrm{~h}$. SR-picolyl chloride hydrochloride and the rest of the diluted $\mathrm{NaOH}$ solution $(6 \mathrm{~mL}$, 4 equiv) were then added dropwisely. $\mathrm{CH}_{2} \mathrm{Cl}_{2}(30 \mathrm{~mL})$ was added to make the bi-phase solution and was vigorously stirred for $2-4$ days. The progress of the reaction can be verified by ESI-MS. The additional concentrated $\mathrm{NaOH}(\mathrm{aq})(1 \mathrm{~mL}, 17 \mathrm{M})$ was treated with the bi-phase solution. The aqueous layer was extracted four times with $30 \mathrm{~mL} \mathrm{CH} \mathrm{Cl}_{2}$. The combined $\mathrm{CH}_{2} \mathrm{Cl}_{2}$ layers were dried over $\mathrm{MgSO}_{4}$. Yellow semi-oil/semi-solid products were achieved by rotary-evaporation under reduced pressure. White powder was obtained by recrystallizing from $\mathrm{MeOH}$. The best yield was around $2.58 \mathrm{~g}$, 
57\%. ESI-MS m/z 467.45 (experimental) 467.33 (calculated); ${ }^{1} \mathrm{H}$ NMR $\left(\mathrm{CDCl}_{3}, 500 \mathrm{~Hz}\right): \delta 8.07$ (s, 2H); $4.05(\mathrm{~d}, J=12.5 \mathrm{~Hz}, 2 \mathrm{H}) ; 3.67(\mathrm{~s}, 6 \mathrm{H}) ; 3.64(\mathrm{~d}, J=10.4 \mathrm{~Hz}, 2 \mathrm{H}) ; 2.75(\mathrm{~s}, 2 \mathrm{H}) ; 2.52-2.58(\mathrm{~m}, 2 \mathrm{H}) ; 2.31(\mathrm{~d}$, $J=13.9 \mathrm{~Hz}, 2 \mathrm{H}) ; 2.20(\mathrm{~s}, 6 \mathrm{H}) ; 2.15(\mathrm{~s}, 6 \mathrm{H}) ; 1.64(\mathrm{t}, J=12.5 \mathrm{~Hz}, 2 \mathrm{H}) ; 1.44-1.51(\mathrm{~m}, 4 \mathrm{H}) ; 0.98-1.14(\mathrm{~m}, 2 \mathrm{H})$; $0.95(\mathrm{~d}, J=11.0 \mathrm{~Hz}, 2 \mathrm{H}) ; 0.73(\mathrm{~s}, 2 \mathrm{H}) .{ }^{13} \mathrm{C} \mathrm{NMR}\left(\mathrm{CDCl}_{3}, 500 \mathrm{MHz}\right): \delta 164.00 ; 158.72 ; 148.00 ; 126.43$; $124.71 ; 59.69 ; 58.98 ; 54.51 ; 48.42 ; 21.05 ; 20.72 ; 19.59 ; 13.21 ; 10.92$.

\subsection{Synthesis of Manganese SR-mesoPYBP Complex}

The reaction was performed under an Ar atmosphere. SR-mesoPYBP ligand $(0.40 \mathrm{~g}, 0.86 \mathrm{mmol})$ was dissolved in $\mathrm{CH}_{2} \mathrm{Cl}_{2}$. $\mathrm{Mn}\left(\mathrm{ClO}_{4}\right)_{2} \cdot \mathrm{xH}_{2} \mathrm{O}$ ( $\mathrm{x}$ was not necessarily to be determined since excess $\mathrm{Mn}\left(\mathrm{ClO}_{4}\right)_{2}$ was added) $(0.65 \mathrm{~g}, 2.58 \mathrm{mmol})$ was dissolved in minimal acetonitrile (no more than $1 \mathrm{~mL}$ ). The solution was combined and stirred for 2 days. The progress of the reaction was tested by ESI-MS. Any precipitant was removed by filtration (excess manganese salts). The white powder was filtered by the dropwise addition of the solution into a large amount of $\mathrm{Et}_{2} \mathrm{O}(>1: 50)$. The best yield was around $0.41 \mathrm{~g}, 66 \%$. ESI-MS (Mn-SR-mesoPYBP $\left.\left(\mathrm{ClO}_{4}\right)^{+}\right) \mathrm{m} / \mathrm{z} 620.36$ (experimental) 620.22 (calculated). Elemental analysis (average of two runs): measured C\%, 46.53 (calculated 46.68); $\mathrm{H} \%, 5.82$ (5.88); N\%, 7.51 (7.78); $\mathrm{Mn} \%, 7.23$ (7.62).

\subsection{General Catalysis Procedure}

The olefin stock solution was prepared by dissolving cyclooctene $(1.3224 \mathrm{~g}, 12 \mathrm{mmol})$ in $3 \mathrm{~mL}$ of acetonitrile. Chlorobenzene $(0.5403 \mathrm{~g}, 4.8 \mathrm{mmol})$ was added into the solution as an internal standard for GC testing. Complex 1 or $2(0.5 \mathrm{~mL}, 1 \mathrm{mM})$ was introduced into the olefin stock solution $(25 \mu \mathrm{L}$, $100 \mu \mathrm{mol}$ cyclooctene and $40 \mu \mathrm{mol}$ chlorobenzene) with appropriate amount of additives (0-5000 equiv $\mathrm{HOAc}$ ) at room temperature. A $5-\mu \mathrm{L}$ solution was injected into $1 \mathrm{~mL}$ of ether as the initial sample. An appropriate amount of $\mathrm{H}_{2} \mathrm{O}_{2}$ was then injected into the solution in five portions in order to start the catalysis reaction. A $5-\mu \mathrm{L}$ solution was injected into $1 \mathrm{~mL}$ of ether as the final sample. These samples were quantitatively analyzed by GC-MS. All of the samples were run at least three times, and the arithmetic means were used to report the data.

\section{Conclusions}

In conclusion, introducing electron-donating substituents on the mesoPYBP ligand improved the catalytic activity of the catalyst in olefin epoxidation with $\mathrm{H}_{2} \mathrm{O}_{2}$ in the presence of acetic acid. We successfully synthesized Complex 2 and optimized its catalytic performance by manipulating the acid loading. Mechanistic studies supported that an electronic effect can stabilize the high-valent intermediates in the PYBP catalytic cycle by maintaining manganese in the complex center. In addition to the metal racPYBP catalysts, the development of active electron-rich metal mesoPYBP catalysts makes the PYBP catalytic system a better candidate for olefin epoxidation. In the future, we want to introduce metal PYBP catalysts to a larger substrate scope, and hopefully offer another high-efficient, low-cost and environmental-friendly way to synthesize epoxides.

Supplementary Materials: The following are available online at http://www.mdpi.com/2073-4344/10/3/285/s1. Figure S1: ESI-MS of SR-mesoPYBP ligand, Figure S2: ${ }^{1} \mathrm{H}$ NMR of SR-mesoPYBP ligand, Figure S3: ${ }^{13} \mathrm{C}$ NMR of SR-mesoPYBP ligand, Figure S4: ESI-MS of complex 2, Figure S5: ESI-MS of Entry 1 solution solution after 60 min reaction time, Figure S6: EPR spectrum for complex 1 at $120 \mathrm{~K}$ at $6 \mathrm{~min}, 30 \mathrm{~min}, 1$ day or more than 1 day, Figure S7: EPR spectrum for complex 2 at 120K at $6 \mathrm{~min}, 30 \mathrm{~min}, 1$ day or more than 1 day, Figure S8: OPTRP diagram of SR-mesoPYBP ligand, Table S1: Complex 1 or 2 catalyzed olefin epoxidation reaction, Table S2: Limiting reagent test.

Author Contributions: Conceptualization, F.Z. and E.V.R.-A.; data curation, F.Z. and A.J.Z.; funding acquisition, E.V.R-A.; investigation, F.Z., G.Y. and A.J.Z.; methodology, F.Z. and G.Y.; project administration, E.V.R-A.; supervision, X.Z.; writing (original draft), F.Z.; writing (review and editing), X.Z. All authors have read and agreed to the published version of the manuscript.

Funding: This research was funded by U.S. Department of Energy, DE-FG02-06ER15799 and National Science Foundation Grant, CHE 1412909. 
Acknowledgments: This work was supported by the U.S. Department of Energy (grant DE-FG02-06ER15799) and the National Science Foundation (grant CHE 1412909). The ESI-MS spectrometer and NMR at Tufts University were supported by the National Science Foundation (grants CHEM-MRI 0320783 and CHE-MRI 0821508). We appreciate Elena Mihilova for the fundamental research of this project. We also would like to thank Samuel W. Thomas, Sergiy Kryatov and Jilin Han for their comments, which greatly improved the manuscript, and Terry Hass for the instrumental supplement.

Conflicts of Interest: The founding sponsors had no role in the design of the study; in the collection, analyses or interpretation of the data; in the writing of the manuscript and in the decision to publish the results.

\section{References}

1. Mikhalyova, E.A.; Makhlynets, O.V.; Palluccio, T.D.; Filatov, A.S.; Rybak-Akimova, E.V. A new efficient iron catalyst for olefin epoxidation with hydrogen peroxide. Chem. Commun. 2012, 48, 687. [CrossRef] [PubMed]

2. Jürgens, E.; Wucher, B.; Rominger, F.; Törnroos, K.W.; Kunz, D. Selective rearrangement of terminal epoxides into methylketones catalysed by a nucleophilic rhodium-NHC-pincer complex. Chem. Commun. 2015, 51, 1897. [CrossRef] [PubMed]

3. Krishnan, K.K.; Thomas, A.M.; Sindhu, K.S.; Anilkumar, G. Recent advances and perspectives in the manganese-catalysed epoxidation reactions. Tetrahedron 2016, 72, 1. [CrossRef]

4. Ottenbacher, R.V.; Samsonenko, D.G.; Talsi, E.P.; Bryliakov, K.P. Highly Enantioselective Bioinspired Epoxidation of Electron-Deficient Olefins with $\mathrm{H} 2 \mathrm{O} 2$ on Aminopyridine Mn Catalysts. ACS Catal. 2014, 4, 1599. [CrossRef]

5. Ottenbacher, R.V.; Talsi, E.P.; Bryliakov, K.P. Bioinspired Mn-aminopyridine catalyzed epoxidations of olefins with various oxidants: Enantioselectivity and mechanism. Catal. Today 2016, 278, 30. [CrossRef]

6. Lane, B.S.; Burgess, K. Metal-catalyzed epoxidations of alkenes with hydrogen peroxide. Chem. Rev. 2003, 103, 2457. [CrossRef]

7. Ottenbacher, R.V.; Talsi, E.P.; Bryliakov, K.P. Direct selective oxidative functionalization of C-H bonds with $\mathrm{H} 2 \mathrm{O} 2: \mathrm{Mn}$-Aminopyridine complexes challenge the dominance of non-heme Fe catalysts. Molecules 2016, 21, 1454. [CrossRef]

8. Milan, M.; Bietti, M.; Costas, M. Aliphatic C-H Bond Oxidation with Hydrogen Peroxide Catalyzed by Manganese Complexes: Directing Selectivity through Torsional Effects. Org. Lett. 2018, 20, 2720. [CrossRef]

9. White, M.C.; Doyle, A.G.; Jacobsen, E.N. A Synthetically Useful, Self-Assembling MMO Mimic System for Catalytic Alkene Epoxidation with Aqueous H2O2. J. Am. Chem. Soc. 2001, 123, 7194. [CrossRef]

10. Costas, M.; Tipton, A.K.; Chen, K.; Jo, D.H.; Que, J. Modeling Rieske Dioxygenases: The First Example of Iron-Catalyzed Asymmetric cis-Dihydroxylation of Olefins. J. Am. Chem. Soc. 2001, 123, 6722. [CrossRef]

11. Murphy, A.; Dubois, G.; Stack, T.D.P. Efficient epoxidation of electron-deficient olefins with a cationic manganese complex. J. Am. Chem. Soc. 2003, 125, 5250. [CrossRef] [PubMed]

12. Makhlynets, O.V.; Oloo, W.N.; Moroz, Y.S.; Belaya, I.G.; Palluccio, T.D.; Filatov, A.S.; Müller, P.; Cranswick, M.A.; Que, L.; Rybak-Akimova, E.V. H 2 O 2 activation with biomimetic non-haem iron complexes and AcOH: Connecting the $\mathrm{g}=2.7 \mathrm{EPR}$ signal with a visible chromophore. Chem. Commun. 2014, 50, 645. [CrossRef] [PubMed]

13. Wu, X.J.; Yang, X.N.; Lee, Y.M.; Nam, W.; Sun, L.C. A nonheme manganese (IV)-Oxo species generated in photocatalytic reaction using water as an oxygen source. Chem. Commun. 2015, 51, 4013. [CrossRef] [PubMed]

14. Ottenbacher, R.V.; Bryliakov, K.P.; Talsi, E.P. Non-Heme Manganese Complexes Catalyzed Asymmetric Epoxidation of Olefins by Peracetic Acid and Hydrogen Peroxide. Adv. Synth. Catal. 2011, 353, 885. [CrossRef]

15. Lyakin, O.Y.; Ottenbacher, R.V.; Bryliakov, K.P.; Talsi, E.P. Dramatic effect of carboxylic acid on the electronic structure of the active species in Fe (PDP)-catalyzed asymmetric epoxidation. ACS Catal. 2012, 2, 1196. [CrossRef]

16. Cussó, O.; Garcia-Bosch, I.; Font, D.; Ribas, X.; Lloret-Fillol, J.; Costas, M. Highly Stereoselective Epoxidation with $\mathrm{H} 2 \mathrm{O} 2$ Catalyzed by Electron-Rich Aminopyridine Manganese Catalysts. Org. Lett. 2013, 15, 6158. [CrossRef] 
17. Cussó, O.; Garcia-Bosch, I.; Ribas, X.; Lloret-Fillol, J.; Costas, M. Asymmetric Epoxidation with H2O2 by Manipulating the Electronic Properties of Non-heme Iron Catalysts. J. Am. Chem. Soc. 2013, 135, 14871. [CrossRef]

18. Zima, A.M.; Lyakin, O.Y.; Ottenbacher, R.V.; Bryliakov, K.P.; Talsi, E.P. Iron-Catalyzed Enantioselective Epoxidations with Various Oxidants: Evidence for Different Active Species and Epoxidation Mechanisms. ACS Catal. 2017, 7, 60-69. [CrossRef]

19. Cussó, O.; Serrano-Plana, J.; Costas, M. Evidence of a Sole Oxygen Atom Transfer Agent in Asymmetric Epoxidations with Fe-pdp Catalysts. ACS Catal. 2017, 7, 5046. [CrossRef]

20. Hölzl, S.M.; Altmann, P.J.; Kück, J.W.; Kühn, F.E. Speciation in iron epoxidation catalysis: A perspective on the discovery and role of non-heme iron (III)-hydroperoxo species in iron-catalyzed oxidation reactions. Coord. Chem. Rev. 2017, 352, 517. [CrossRef]

21. Yazerski, V.A.; Spannring, P.; Gatineau, D.; Woerde, C.H.M.; Wieclawska, S.M.; Lutz, M.; Kleijn, H.; Klein Gebbink, R.J.M. Making Fe (BPBP)-catalyzed C-H and C [double bond, length as m-dash] C oxidations more affordable. Org. Biomol. Chem. 2014, 12, 2062. [CrossRef] [PubMed]

22. Yang, G.; Rybak-Akimova, E.V.; Campana, C. $\{1$, 1'-Bis [(pyridin-2-yl) methyl]-2, 2'-bipiperidyl $\}$ (perchlorato) copper (II) perchlorate. Acta Crystallogr. Sect. E Crystallogr. Commun. 2017, 73, 1082. [CrossRef] [PubMed]

23. Yang, G. Bioinspired mononuclear transition-metal aminopyridine complexes for olefin epoxidation and molecular oxygen activation: Synthesis, characterization, catalysis and mechanistic studies. Ph.D. Thesis, Tufts University, Medford, MA, USA, 2017.

24. Costas, M.; Que, L., Jr. Ligand topology tuning of iron-catalyzed hydrocarbon oxidations. Angew. Chem. Int. Ed. 2002, 41, 2179. [CrossRef]

25. Saravanan, N.; Sankaralingam, M.; Palaniandavar, M. Manganese(ii) complexes of tetradentate $4 \mathrm{~N}$ ligands with diazepane backbones for catalytic olefin epoxidation: Effect of nucleophilicity of peroxo complexes on reactivity. RSC Adv. 2014, 4, 12000. [CrossRef]

26. Hubin, T.J.; McCormick, J.M.; Collinson, S.R.; Buchalova, M.; Perkins, C.M.; Alcock, N.W.; Kahol, P.K.; Raghunathan, A.; Busch, D.H. New iron (II) and manganese (II) complexes of two ultra-rigid, cross-bridged tetraazamacrocycles for catalysis and biomimicry. J. Am. Chem. Soc. 2000, 122, 2512. [CrossRef]

27. Cavallo, L.; Jacobsen, H. J Electronic effects in (salen)Mn-based epoxidation catalysts. J. Org. Chem. 2003, 68, 6202. [CrossRef]

28. Goldsmith, C.R.; Jiang, W. Alkene epoxidation catalyzed by manganese complexes with electronically modified 1,10-phenanthroline ligands. Inorg. Chim. Acta. 2012, 384, 340. [CrossRef]

29. Odom, B.; Hanneke, D.; D'urso, B.; Gabrielse, G. New measurement of the electron magnetic moment using a one-electron quantum cyclotron. Phys. Rev. Lett. 2006, 97, 6. [CrossRef]

30. Ottenbacher, R.V.; Bryliakov, K.P.; Talsi, E.P. Nonheme manganese-catalyzed asymmetric oxidation. A Lewis acid activation versus oxygen rebound mechanism: Evidence for the "Third Oxidant". Inorg. Chem. 2010, 49, 8620. [CrossRef]

31. Larrow, J.F.; Jacobsen, E.N. (R, R)-N, N'-BIS (3， 5-DI-TERT-BUTYLSALICYLIDENE)-1, 2-CYCLOHEXANEDIAMINO MANGANESE (III) CHLORIDE, A HIGHLY ENANTIOSELECTIVE EPOXIDATION CATALYST:(MANG ANESE, CHLORO 2, 2'-1, 2-CYCLOHEXANEDIYLBIS (NITRILOMETHYLIDYNE)-BIS4, 6-BIS (1, 1-DIMETHYLETHYL) PHENALATO (2-)-N, N', O, O'-, SP-5-1 3-(1 R-TRANS-). Org. Synth. 1998, 75, 1.

32. Mas-Balleste, R.; Que, L. Iron-catalyzed olefin epoxidation in the presence of acetic acid: Insights into the nature of the metal-based oxidant. J. Am. Chem. Soc. 2007, 129, 15964. [CrossRef] [PubMed]

33. Du, J.; Miao, C.; Xia, C.; Lee, Y.M.; Nam, W.; Sun, W. Mechanistic Insights into the Enantioselective Epoxidation of Olefins by Bioinspired Manganese Complexes: Role of Carboxylic Acid and Nature of Active Oxidant. ACS Catal. 2018, 8, 4528. [CrossRef]

34. Ottenbacher, R.V.; Talsi, E.P.; Bryliakov, K.P. Chiral Manganese Aminopyridine Complexes: The Versatile Catalysts of Chemo- and Stereoselective Oxidations with H2O2. Chem. Rec. 2018, 18, 78. [CrossRef] [PubMed]

(C) 2020 by the authors. Licensee MDPI, Basel, Switzerland. This article is an open access article distributed under the terms and conditions of the Creative Commons Attribution (CC BY) license (http://creativecommons.org/licenses/by/4.0/). 